\title{
Geologic process studies using Synthetic Aperture Radar (SAR) data
}

Numerical models of climatic processes offer the promise of simulating future global trends; however, it is crucial for us to understand how changes in climate are manifested locally before we can evaluate the true impact of climate change. Thus, increased awareness and concern about global climate change have led to an equal interest in remote sensing as a tool for mapping and monitoring changes in the land surface and cover.

Geologic processes, such as soil erosion, transportation, deposition, and degradation, affect not only the amount of arable land available for cultivation but also have an impact on sedimentation in estuaries, deltas, and other coastal environments. Additional geologic processes, such as tectonism and volcanism, have a profound impact on human life as well. These additional processes become modulators of global climate not only through destructive seismic activity but also through the influence of volcanoes on the chemistry of the oceans and atmosphere and through eruptions of gases and particulates into the stratosphere.

Synthetic Aperture Radar plays an important role in landform mapping and structural interpretation because viewing geometries can be optimized for different terrain types in a way similar to that used for low sun-angle aerial photography. In addition, radar data are important for geologic process studies because unique quantitative information about surface roughness, vegetation extent, soil moisture, topography, and topographic change can be extracted from calibrated data sets.

\section{Introduction}

The image brightness of Synthetic Aperture Radar (SAR) is related to radar backscatter at the pixel level, and it is a function of slope, surface roughness, dielectric constant, and subsurface discontinuities. Therefore, it provides intrinsic physical information about surfaces and volumes that complement measurements made by sensors operating in the visible, shortwave infrared, and thermal infrared parts of the electromagnetic spectrum.
Radar sensors provide their own illumination and, as a result, can provide reliable multitemporal data that are independent of weather or sun illumination through all seasons and at all latitudes. Radar waves penetrate through clouds and, under certain conditions, through vegetation canopies and thin veneers of alluvial overburden, which makes it possible to explore regions of the Earth's surface that are not accessible by the use of other remote sensing techniques.

Geologic processes that are particularly amenable to studies employing SAR data include volcanism; soil erosion, degradation, and redistribution; coastal erosion and inundation; glacier fluctuations; permafrost; and crustal motions. Such process studies are critical not only to our understanding of recent tectonic activity and climate change but also to the mitigation of geologic hazards and to exploration for nonrenewable resources.

Sensors flying now, as well as those planned for flight in the 1990 s, provide an opportunity to develop models and test methods for large-scale mapping, geophysical processing, and the generation of high-resolution digital elevation models that will make it possible to use SAR data routinely for global process studies. Data acquired from airborne sensors such as the Airborne Imaging Radar (AIRSAR), which was developed by the National Aeronautics and Space Administration's Jet Propulsion Laboratory (JPL), are being used for investigations that focus on fairly small test sites (figs. 1-3). Data from the Shuttle Imaging Radars (SIR-C and X-SAR), scheduled for flights in 1993, 1994, and 1996, will expand these studies to regional scales; and the Earth Observing System (EOS) SAR, planned later in the decade, will provide both global coverage and a monitoring capability.

When data from these systems are combined with data from other planned spaceborne sensors, such as the European Space Agency's (ESA) European Remote Sensing satellites (ERS-1 and ERS-2), the Japanese Earth Resources Satellite (JERS-1), and the Canadian Radarsat, it will be possible to build a time-series view of temporal changes over many regions of the Earth. Operating parameters for these SAR systems are given in table 1. Key geophysical products that will be derived in support of geologic process studies from the resulting data are given in table 2 . The status of our current capability to generate these geophysical products is described below.

\section{Landform mapping}

Exploitation of radar data for geological studies has advanced most in the area of landform mapping. Several studies have shown the value of SAR images for mapping structures in volcanic and sedimentary terranes (Greeley and Martel, 1988; Campbell and others, 1989; Gaddis and others, 1989; Sabins, 1983; Wadge and Dixon, 1984; Lynne and Taylor, 1986) and for studying the processes of erosion, weathering, and deposition (see Blom and Daily, 1982; Evans, 1988; Arvidson and others, in press).

Images from the Shuttle Imaging Radars (SIR-A and SIR-B) of the eastern Sahara in northern Africa revealed the capability of spaceborne radars' providing insight into the geologic record that is 


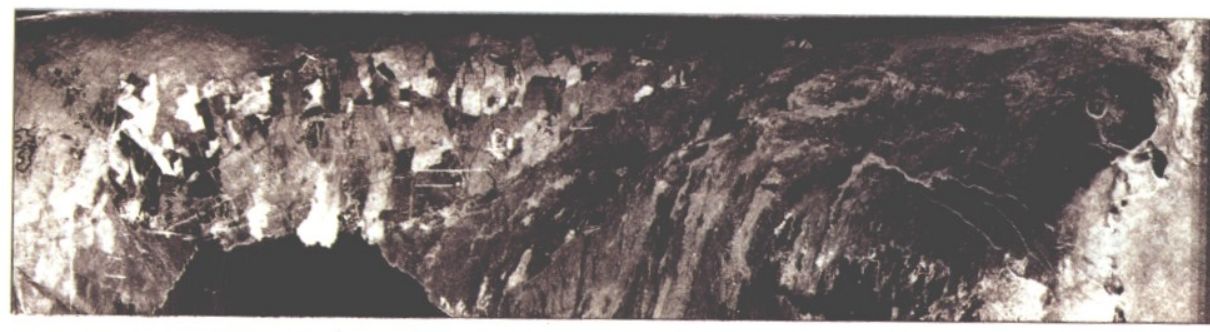

\section{PHH}

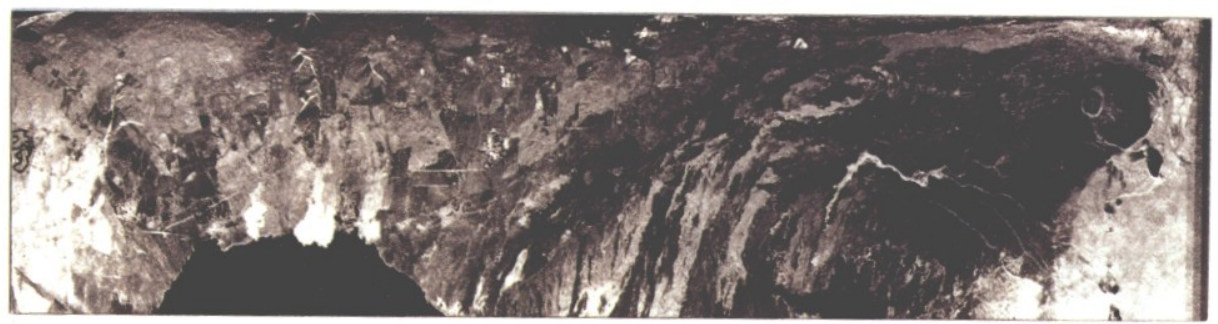

\section{LHH}

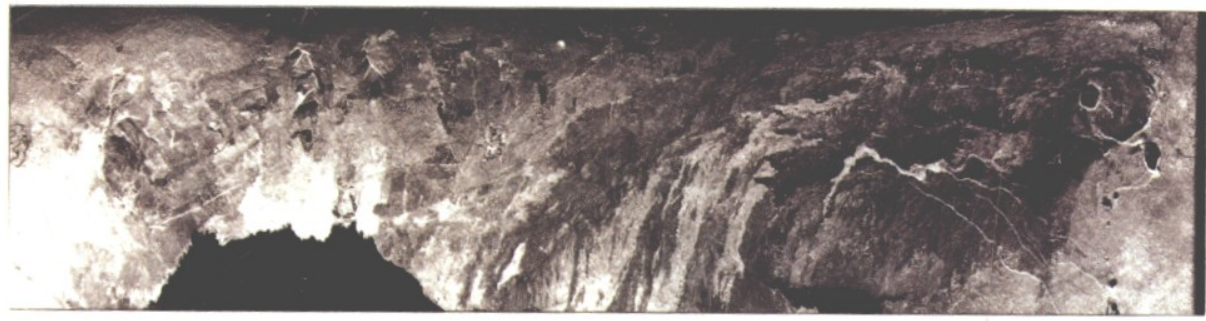

\section{$\mathrm{CHH}$}

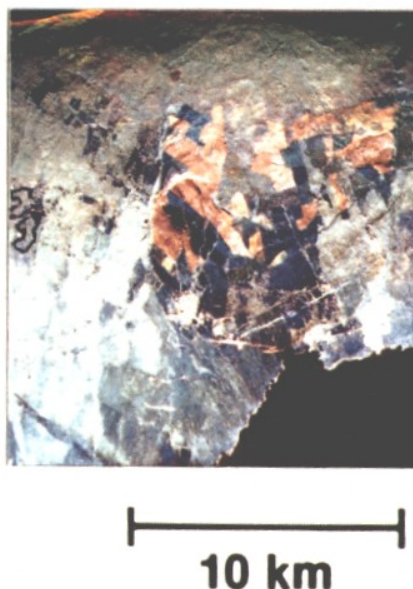

Figure 1.-Multifrequency AIRSAR images of Kilauea Crater, Hawaii, USA, showing lava flows of varying ages and surface roughness. Images such as these will be used to support the Earth Observing System's (EOS) volcanology investigation (for example, see Mouginis-Mark and others, 1991). See table 1 for explanation of abbreviations.

buried beneath thin deposits of windblown sand and is masked from sensors that operate in the visible part of the spectrum (McCauley and others, 1982; McCauley and others, 1986; Schaber and others, 1986). Subsequent reexamination of data acquired in 1978 from the Seasat satellite and in 1988 from AIRSAR showed that significant penetration also occurred in the Mojave Desert of southern California, USA, which indicates that subsurface features of potential tectonic significance may be revealed in radar images of semiarid terranes (Blom and others, 1984) (fig. 4).

Several techniques have been developed that may result in automated landform mapping. For example, a technique that can be used to map textural variations was described by Blom and Daily
(1982) and was used by Stromberg and Farr (1986). The technique involves the production of images that represent only certain scales of texture. This is accomplished first by filtering the Fourier transform of an area into several spatial frequency bands and then by producing an image for each of these bands. These bandpass images are used next in a standard, unsupervised classification algorithm in order to produce a map, the units of which represent unique textural signatures. One also could use images in which pixels represent local variance, or other statistical quantities, in different sized boxes in the classification algorithm. These techniques not only discriminate units that are based on texture, but they produce a spatial frequency signature for the units as well. These signatures allow the comparison 

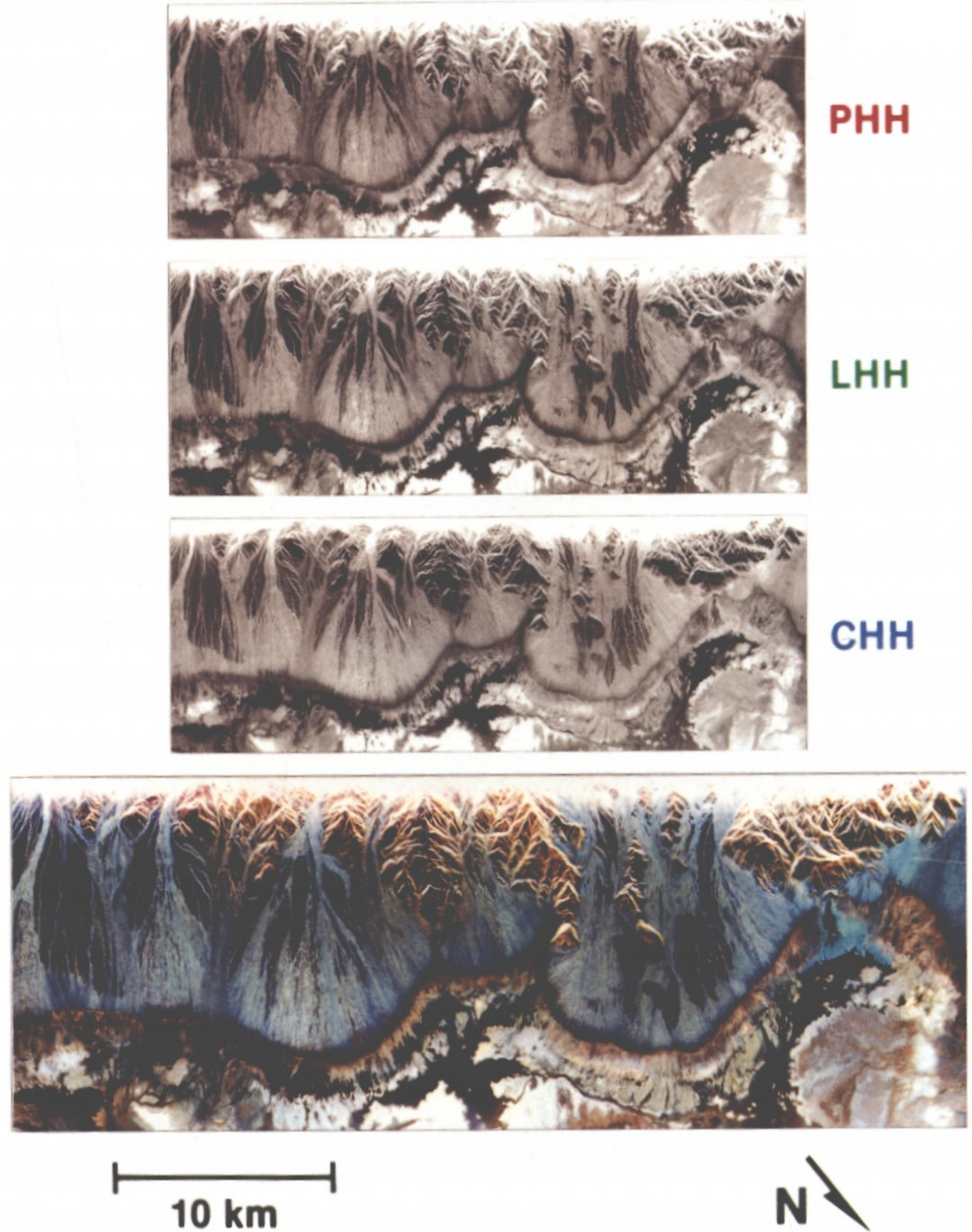

Figure 2.-Multifrequency AIRSAR images of Death Valley, California, USA, showing alluvial fan units of varying ages and surface roughness. Such images will be used to determine the relative ages of geomorphic surfaces, information that is required for studies of modern erosion rates, past climate fluctuations, and dating of young faults.

of units between maps and may allow the identification of rock types if adequate knowledge exists about the climate, tectonic history, and response of different rock types to these factors.

\section{Surface roughness}

Weathering and depositional processes generally cause surfaces to smooth as they age, whereas erosional processes can cause a rough- ening of surfaces. The scales of these processes are different, and their rates vary as a result of climate, rock type, and geologic structure. However, their effects can be used to date surfaces relatively for studies of climatic change and tectonic history. In cases where numerical ages exist, average process rates over time also may be derived.

Microtopography or surface roughness is the link between weathering and depositional processes and radar remote sensing data. 


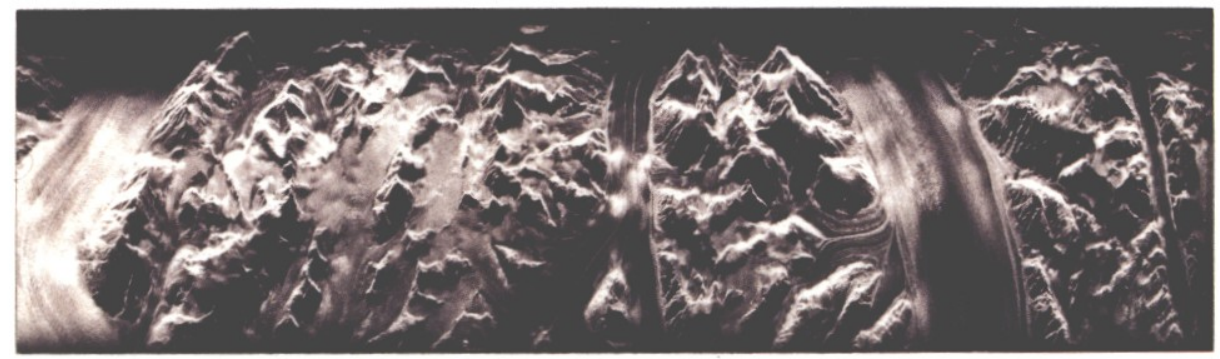

\section{PHH}

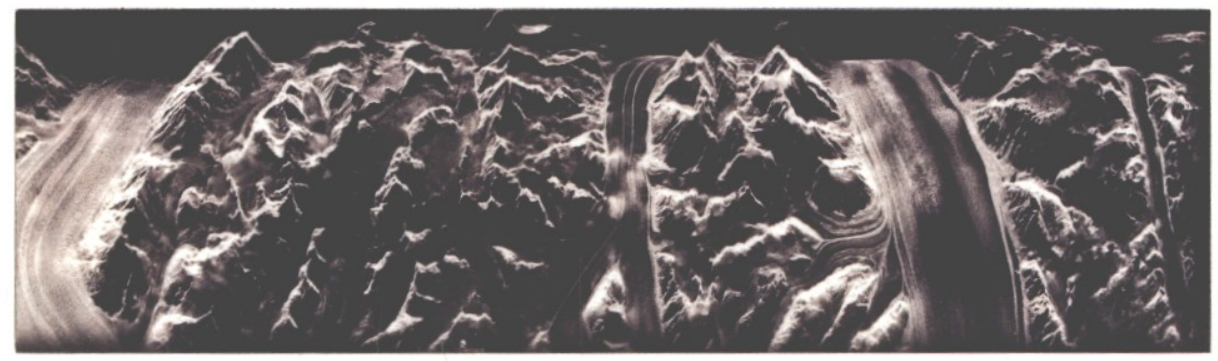

\section{LHH}

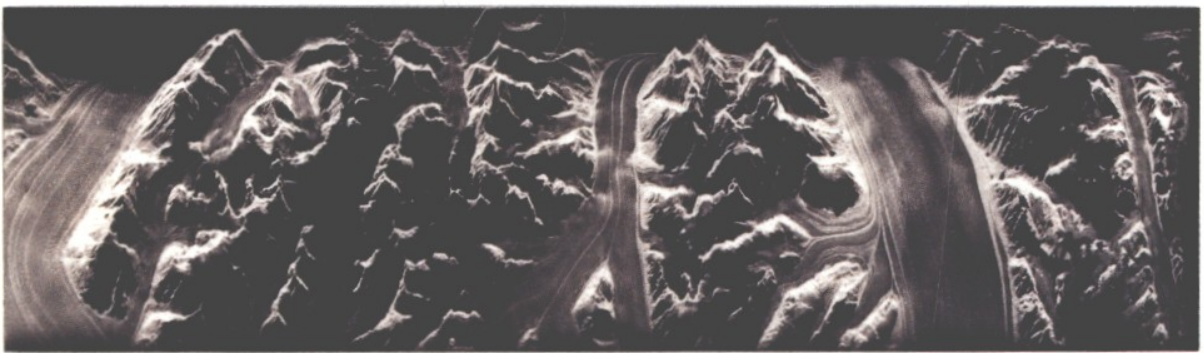

\section{$\mathrm{CHH}$}

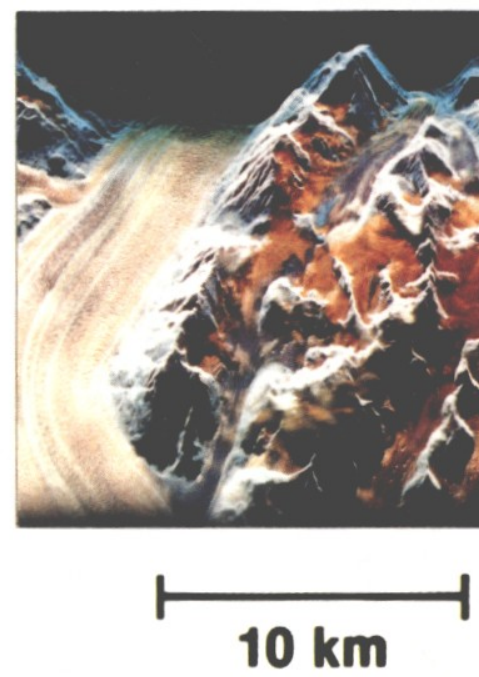

Figure 3.-Multifrequency AIRSAR images of glaciers near the southwest coast of Greenland showing variations in both surface and subsurface structure. Images such as these will be used in order to study changes in glacier mass balance (see Rott, 1990; Jezek and others, 1991).

Work by van Zyl and others (1991) showed that surface microtopography could be inferred from multifrequency SAR data by the inversion of a radar backscatter model. In that study, physical properties were measured at three different $10 \mathrm{~m}$ by $10 \mathrm{~m}$ sites representing surfaces that had root mean square (rms) heights varying from less than $1 \mathrm{~cm}$ to tens of centimeters. Ground measurements included soil moisture content, dielectric constant, and microtopographic profiles. The profiles were generated from helicopter photography using twin metric framing cameras that was reduced later to profiles covering $10-30 \mathrm{~m}$ at $1-\mathrm{cm}$ spacing, which allowed the estimation of the power spectrum, rms height, and correlation length of the surfaces (Wall and others, 1991). AIRSAR data acquired at three different incidence 
Table 1.-Operating parameters of examples of current and future SAR systems

[Abbreviation: N/A, not applicable]

\begin{tabular}{|c|c|c|c|c|c|c|}
\hline & AIRSAR & ERS-1 & $S I R-C X-S A R$ & JERS-1 & RADARSAT & EOS SAR \\
\hline Spectral coverage' & P.L,C & $\mathrm{C}$ & L,C,X & $\mathrm{L}$ & $\mathrm{C}$ & L,C,X \\
\hline Polarization $^{2}$ & Quad & VV & $\begin{array}{r}\text { Quad (C,L) } \\
\text { VV }(X)\end{array}$ & $\mathrm{HH}$ & $\mathrm{HH}$ & $\begin{array}{r}\text { Quad (L) } \\
\text { Dual }(C, X)\end{array}$ \\
\hline Look angle (degrees) & $15-60$ & 23 & $15-60$ & 35 & $20-50$ & $15-40$ \\
\hline Resolution (m) & 10 & 30 & 25 & 30 & $10-100$ & $20-250$ \\
\hline Swath coverage $(\mathrm{km})$ & 12 & 100 & $10-150$ & 80 & 50.500 & $30-500$ \\
\hline Orbit altitude $(\mathrm{km})$ & 10 & 800 & 215 & 568 & 792 & 620 \\
\hline Orbit inclination (degrees) & $\mathrm{N} / \mathrm{A}$ & 98 & 57 & 98 & 98.6 & 98 \\
\hline Launch date & $\mathrm{N} / \mathrm{A}$ & 1991 & $\begin{array}{l}1993 \\
1994 \\
1996\end{array}$ & 1992 & 1994 & 1999 \\
\hline $\begin{array}{l}\text { X-band wavelength is }-3 \mathrm{~cm} \\
\text { C-band wavelength is } \sim 5.6 \mathrm{~cm} \\
\text { L-band wavelength is }-24 \mathrm{~cm} \\
\text { P-band wavelength is } \sim 68 \mathrm{~cm}\end{array}$ & & & \multicolumn{4}{|c|}{$\begin{array}{l}{ }^{2} \mathrm{HH} \text {, horizontally transmitted, horizontally received wave } \\
\text { VV, vertically transmitted, vertically received wave } \\
\text { Quad =-amplitude and phase of returned wave are both re- } \\
\text { corded so that any combination of transmit and receive } \\
\text { polasization can be sythesized through ground processing }\end{array}$} \\
\hline
\end{tabular}

tble 2.-Examples of solid Earth products that are required om EOS SAR data

ibreviation: ress. resolution. -, not applicable?

\begin{tabular}{|c|c|c|c|c|}
\hline Priducts & Units & Accuracy & $\begin{array}{c}\text { Horizont:i] } \\
\text { res }\end{array}$ & $\begin{array}{l}\text { Temporit } \\
\text { res }\end{array}$ \\
\hline $\begin{array}{l}\text { Geologic feature } \\
\text { distribution }\end{array}$ & $\mathrm{m}$ & 30 & $30 \mathrm{~m}$ & $\begin{array}{l}3 \text { months, } \\
\text { once }\end{array}$ \\
\hline $\begin{array}{l}\text { Surface roughness. } \\
\text { high res }\end{array}$ & $\operatorname{cm}$ & $5 \cdots 10 \%$ & $30 \mathrm{~m}$ & $\begin{array}{l}1 \text { vear. } \\
\text { once }\end{array}$ \\
\hline $\begin{array}{l}\text { Surface roughness, } \\
\text { low res }\end{array}$ & $\mathrm{cm}$ & 10 & $25 \mathrm{kml}$ & 1-2 weeks \\
\hline $\begin{array}{l}\text { Vegetation extent. } \\
\text { high res }\end{array}$ & 一 & $10 \%$ & $30 \mathrm{~m}$ & $\begin{array}{l}1 \text { season. } \\
1 \text { year }\end{array}$ \\
\hline $\begin{array}{l}\text { Iand topography. } \\
\text { high res }\end{array}$ & $\mathrm{m}$ & $5-10$, vertical & $30 \mathrm{~m}$ & Once \\
\hline $\begin{array}{l}\text { Topographic } \\
\text { change }\end{array}$ & $\mathrm{cm}$ & 10 , vertical & $30 \mathrm{~m}$ & $\begin{array}{l}\text { After } \\
\text { event }\end{array}$ \\
\hline Soil moisture & - & $10-25$ & $601-100 \mathrm{~m}$ & 1 week \\
\hline
\end{tabular}

mgles and three wavelengths over the test site were calibrated by aing trihedral corner reflectors that were deployed in the area prior a) obtaining the images in order to provide radar backscatter values $\left(\sigma^{2}\right)$ tor each resolution element in the scenes (van Zyl, 1990). The radar backscatter model was used next in order to infer the power ipectra of surtace microtopography for the three surfaces, and the power spectra were compared to the field measurements. The result was that van $Z_{y} 1$ and others 11991 , found a close match between the sstimated and measured surface microtopography.

Evans and others (in press) extended this work to the Cima oolcanic field in California and the Lunar volcanic field in Nevada. I.SA. They not only found a close match between the estimated and measured surface microtopography. but they also confirmed work by Farr (in press, that showed that surface roughness changes can be correlated with age.

In order to determine the areas of an image for which the radar backscatter model is valid, van 7yl (1989) described an unsupervised classification technique that provides a means 10 segment images into classes displaying different types of scattering. The algorithm classi- fics scatterers into one of threc type on the basis of the polarization characteristics of the transmitted and received waves. The three scattering classes aro single retiection. double bounce. and diftuse scattering. For single reflection trom a slightly rough dielectric surface. the incident wave will experience little multiple scatter. A dihedral reflection exhibus a double-bounce geometry and results in a 180 -degree phate shift beween horizontally transmitted-horizontally recelved $(\mathrm{HH})$ wases and vertically transmitted-vertically received ( $\mathrm{V}$ ) waves. For diffuse scattering. highly varying phase differences of $\mathrm{HH}$ to $\mathrm{V}$ expibit a noiselike character. The orientation angle of the average scattered wave tracks that of the transmitted wave, a behavior that is similar to the behavior observed for the singlereflection case. However. the sense of rotation of the scattered wave is the same as that of the transmitted wave polatization. which is more consistent with a double-bounce mechanism. Papers by ran $2 y$ (1989) and Elans and others (1988) noted that this behavior is generated by a elass of "three-layer" vegetation models, such as the one discussed in san Zyl (1985), Richards and others (1987), and Durden and others (19891. The classification technique was used by Evans and others $(1988)$ in order to map clearcut areas in a Maine. LSA. forest that were not discernable in $\mathrm{L}$-band $\mathrm{HH}$ and $\mathrm{VV}$ images. Evans and van $Z y](1990)$ also used this technique for differentiating areas that had been hurned recently near Mt. Shasta in Californiat. LSA. as did Evans and others (1988) and Evans and Smith (1991) for differentiating arcas having less than 10 percent vegetation cover in a semiarid region in Wyoming. LSA. Figure 5 shows these two examples and a classification map for the area around Kilauca Crater. Hawaii. USA. In each of these examples, the radar backscatter model is valid for roughness scales on the order of one-half the radar wavelength for areas that are classified as single reflections for all three frequencies.

\section{Soil moisture}

Soil moisture is a hydrologic storage variable. as well as an indicator of moisture fluxes, and is. therefore. a critical parameter for many earth science investigations. SAR images have been applied successfully to map saturated soils in temperate regions (Waite and others. 1981: Krohn and others. 1983; Ormsby and others. 1985; Evans and others, 1986: Imhoff and others, 1986, 1987). This success largely 

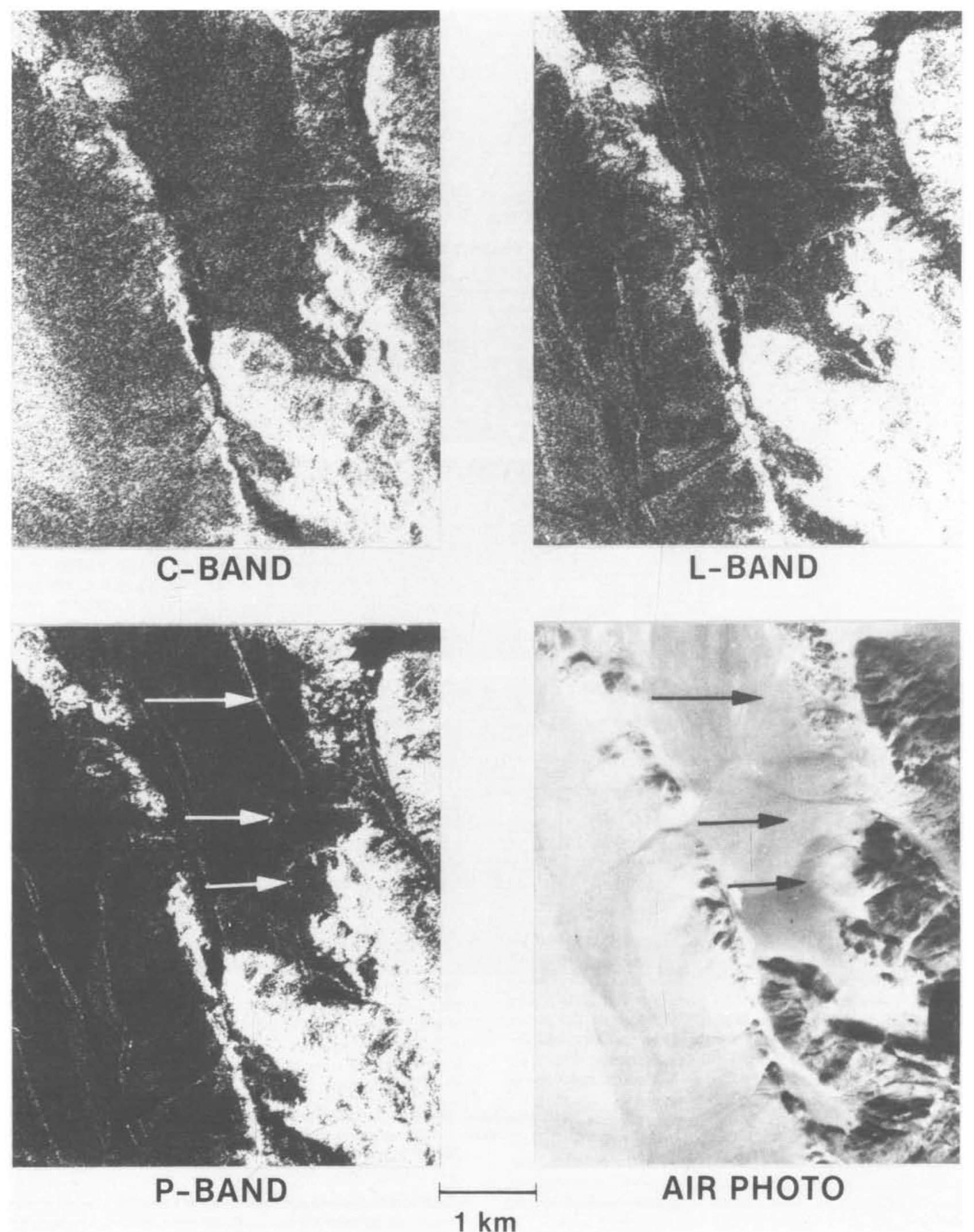

Figure 4.-Comparison of multifrequency AIRSAR images over Means valley in the Mojave Desert of California, USA. Features at arrows in P-band image, which are seen to some extent in the L-band, are shallow subcrops and a dike. 

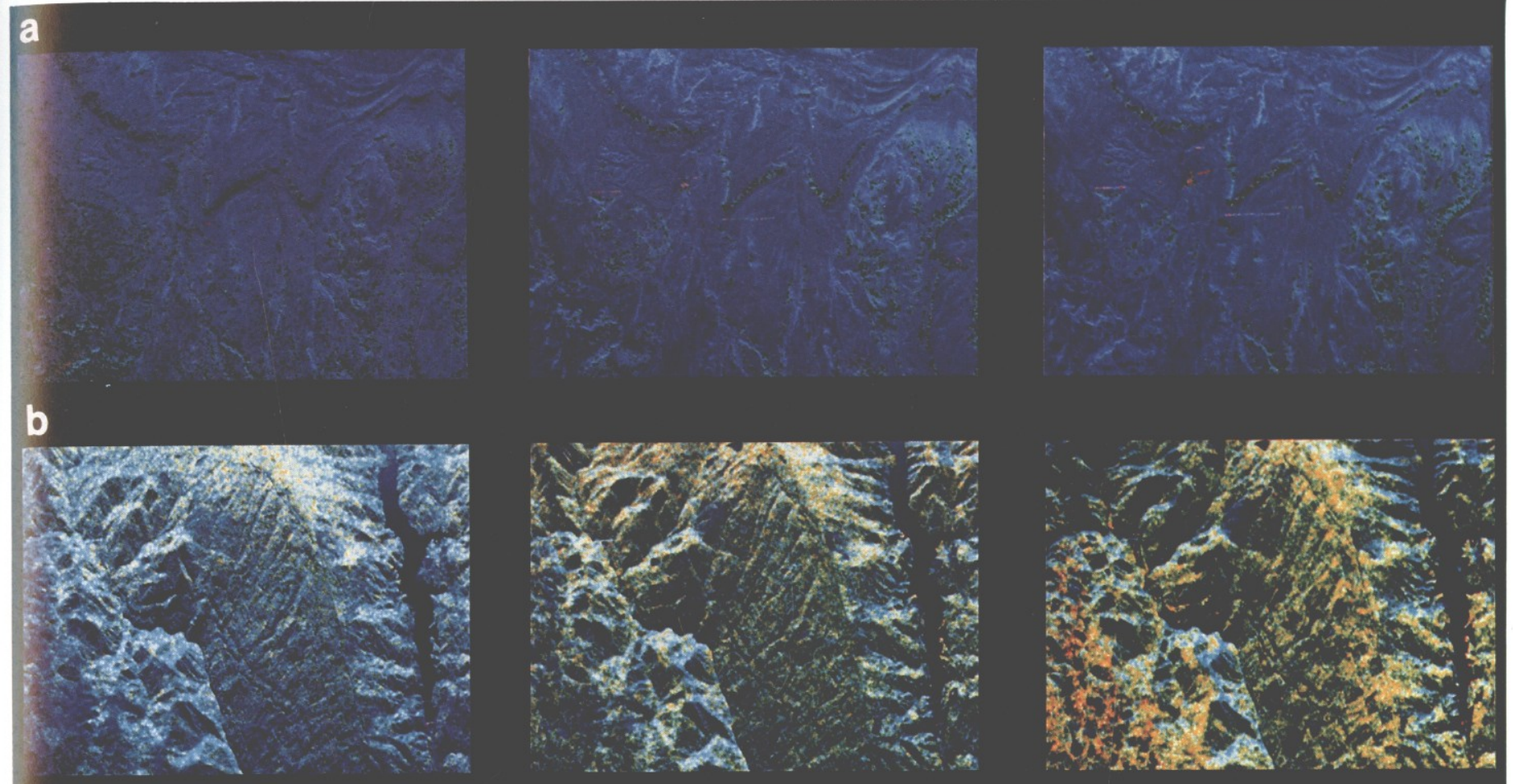

C

\section{C-BAND}

L-BAND

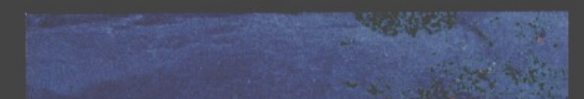

Figure 5.-Classification results based on $C-, L-$, and P-band polarimetric AIRSAR data of (a) Wind River basin of Wyoming; (b) Mt. Shasta, California; and (c) Kilauea Crater, Hawaii, USA. Pixels classified in red are consistent with a double bounce; in blue, with a single reflection; and in green, with diffuse scattering. According to Evans and others (1988) and Evans and Smith (1991), areas having less than 10 percent vegetation cover in the Wind

results from the cloud penetration capabilities of radar and the enhanced backscatter that results from standing water beneath vegetation canopies. This backscatter enhancement, modeled by Engheta and Elachi (1982), is caused by forward scattering of waves from stems (or trunks) and the flooded surface (double bounce). L-band backscatter enhancement from flooded vegetation also has been noted in the Tropics from 12.5-m-high mangroves in Bangladesh (Imhoff and others, 1986, 1987), from 10-12-m-high swamp forests in Guatemala (K.O. Pope, written communication, 1987), and from 7-10m-high swamp forests in Borneo (Ford and Casey, 1988).

Change detection techniques are being investigated in order to assess their applicability to monitoring changes in soil moisture in
River example are classified as single reflection. In the Mt. Shasta example, Evans and van $\mathrm{Zyl}$ (1990) found that areas that had been burned recently allowed additional penetration into the canopy, which results in the increased double bounce at the P-band in the lower left of the image. In the Kilauea example, the forest canopy is so dense on the right edge of the image that very little return resulted from the ground under the vegetation.

less humid environments by the use of the ratios of images. An example of the detection of soil moisture change from multitemporal coverage (fig. 6) was described in Evans (in press).

Multitemporal SAR data were acquired in support of soil moisture studies at Mahantango Creek, Pennsylvania (Engman and others, 1991), and Walnut Gulch, Arizona (Dubois and others, 1991), in the USA in the summer of 1990. Results of these experiments were incorporated into the planning for additional SAR soil moisture experiments flown in Europe in 1991. Multitemporal aircraft data and correlative field measurements were acquired at Slapton Wood, UK; Orgeval, France; Montespertoli, Italy; and Castilla La Mancha, Spain, as part of the deployment. 


\section{Topography and topographic change}

Topography is required in order to complete the three-dimensional view of surface properties and to correct the distortions that are inherent in SAR images. Active microwave techniques that use interferometry may provide a feasible method for acquiring these data. Zebker and Goldstein (1986) showed the feasibility of generating topographic data bases through the use of radar interferometry. Mission studies and the development of aircraft prototypes are underway for the purpose of investigating a variety of methods for the acquisition of a global topographic data base from space (Cumming and others, 1990; Goldstein and others, 1988).

NASA's JPL has implemented an aircraft interferometer that is similar to the one described by Zebker and Goldstein (1986). For the JPL system, the phase difference image that results from combining the two complex data sets has been used to generate topographic data having an rms error of typically $2-5 \mathrm{~m}$ for a $10 \mathrm{~m}$ by $10 \mathrm{~m}$ pixel (Zebker and others, in press). These data are acquired in a single polarization state at C-band simultaneously along with standard L- and P-band polarimeter data so that the data are registered automatically.
In order to address problems at the global scale, discussions are taking place about the generation of a high-resolution digital elevation model of the entire globe, which could serve as a topographic data base for all remote sensors. Among possible options for spaceborne interferometry is the use of subsequent passes of the EOS SAR or two antennas separated on a single structure or by a tether on a dedicated spacecraft. Once the baseline topography is determined, a third interferometric pass can be used to determine what, if any, topographic change has occurred in the intervening time between SAR overpasses (Gabriel and others, 1989). The near cancellation of systematic errors is possible, and sensitivity to topographic change on the order of tens of centimeters is attainable (fig. 7). The extreme sensitivity of this technique to elevation changes, its high spatial resolution (typically $10-30 \mathrm{~m}$ ), and its broad swath coverage mean that it could be used to monitor erosion, sand encroachment, and soil shrinking and swelling (Gabriel and others, 1989). It also may be used to make extensive, accurate measurements of geophysical phenomena, including warping and buckling in fault zones, plate motions, and residual displacements from seismic events.

The use of SAR interferometry will be tested extensively for geological studies as part of the ERS-1 mission. Current plans are to monitor changes in surface topography due to eruptions (either

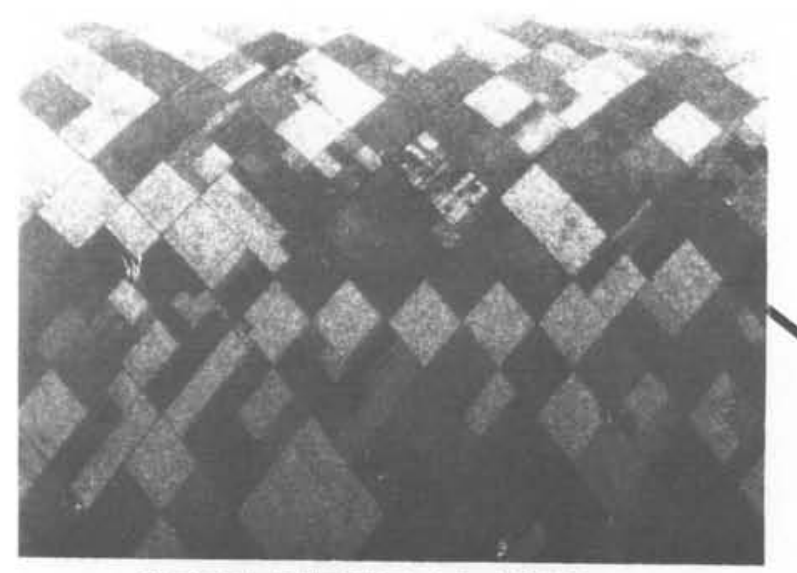

SEPTEMBER 14, 1989
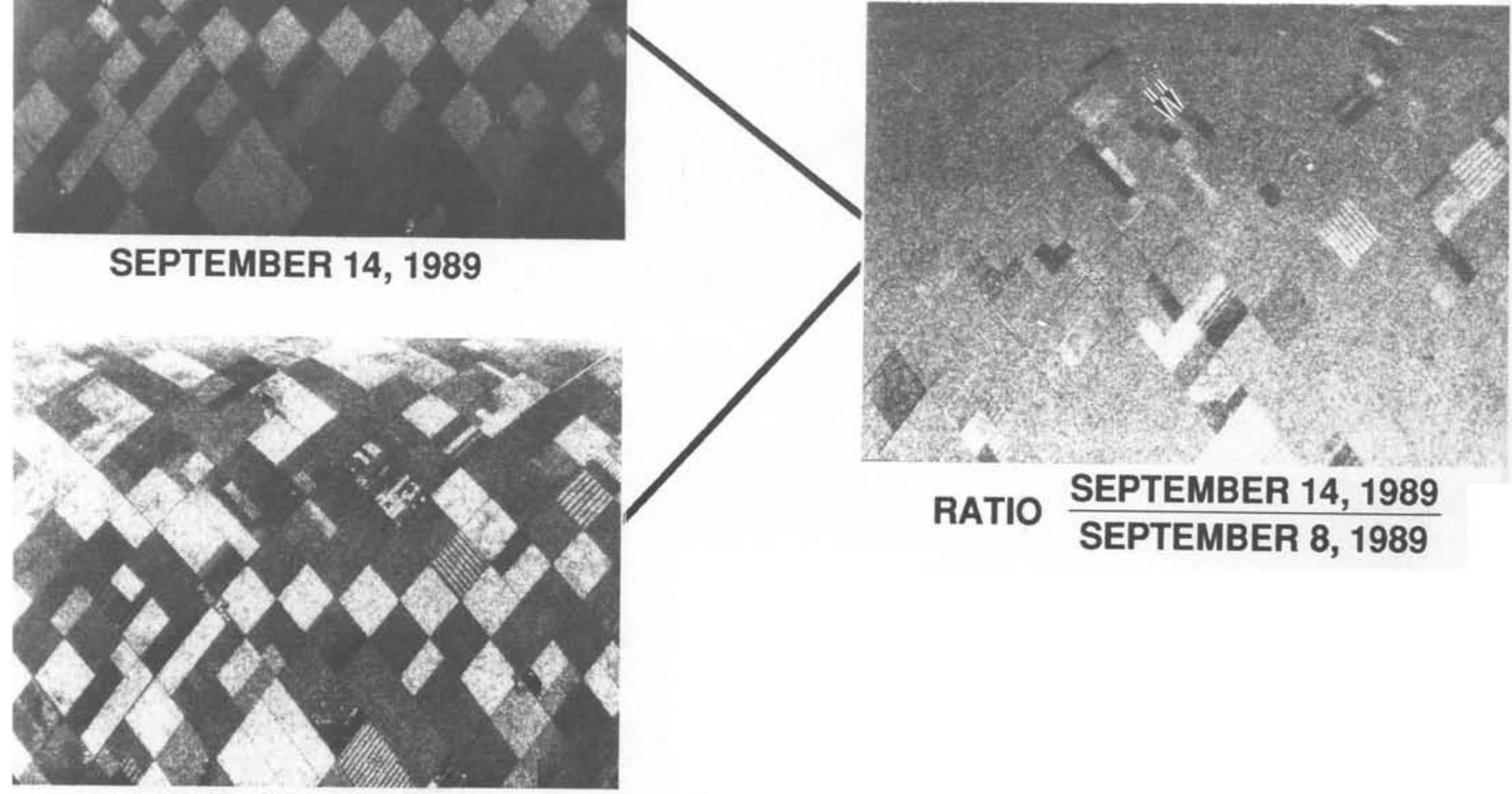

RATIO SEPTEMBER 14,1989

\section{SEPTEMBER 8, 1989}

Figure 6. - Example of the ratio of multitemporal images for a soil moisture study area near Fresno, California, USA. Gray field (left arrow) showed no apparent difference in moisture between the 2 days in this CVV image. Dark field (right arrow) was drier on the second day. Courtesy of E. Engman and J.J. van $\mathrm{Zyl}$, modified from Evans (in press). 


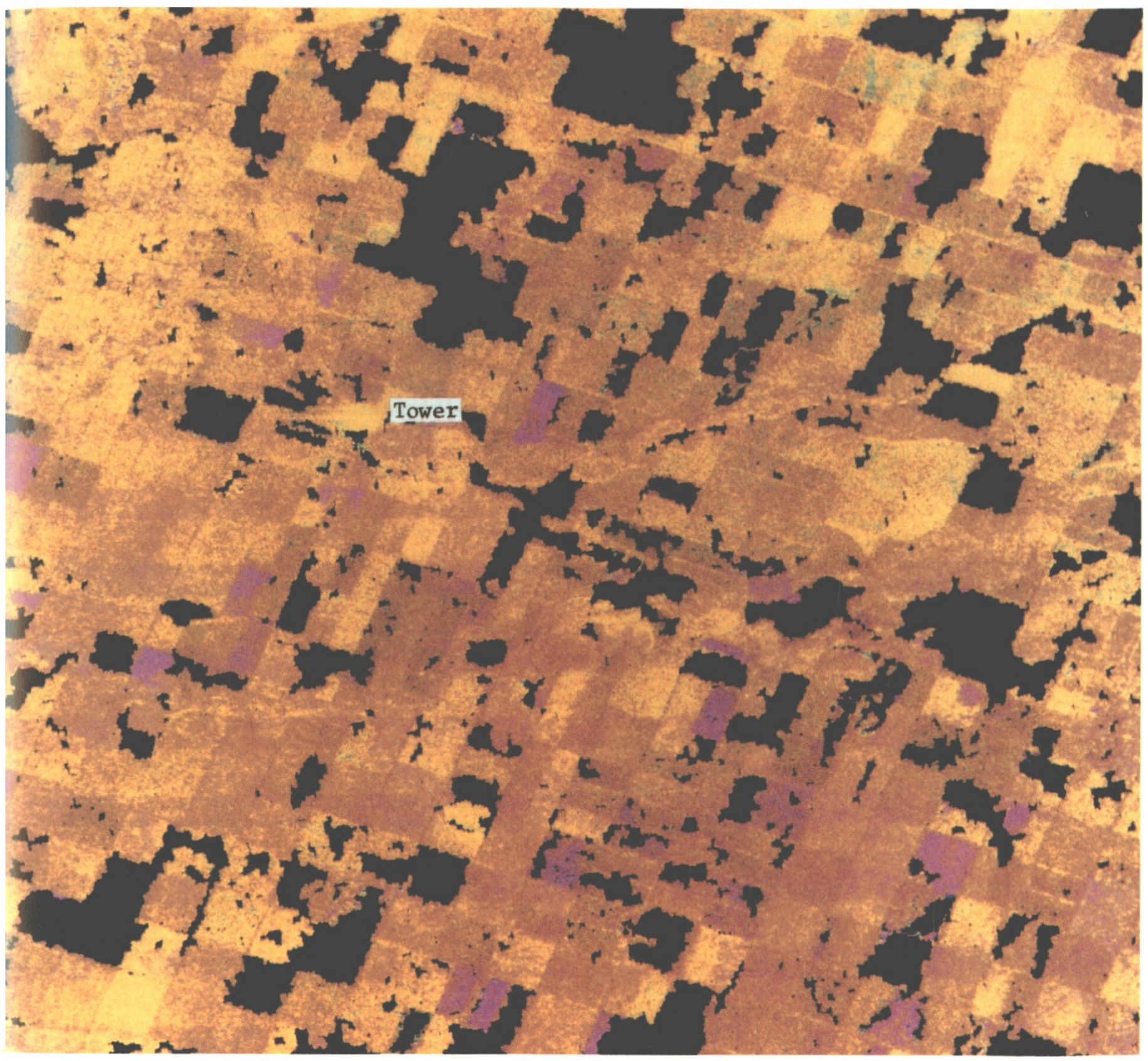

Figure 7. - Image showing topographic changes derived from Seasat SAR data over an area in the Imperial Valley of California, USA. Yellow represents no change, black represents loss of phase coherence between the data sets, and red and blue represent changes in topography on the order of 2-3 cm. These changes were interpreted to be related to soil swelling as a result of irrigation. Taken from Gabriel and others (1989). 
explosive activity or events that produce lava flows) and to swelling of the flanks of volcanos because of the intrusion of magma at a shallow depth; frost-heave displacement in regions of both continuous and discontinuous permaftost; and the topography, motion, and disturbances of glaciers.

\section{A look to the future}

$M_{\text {ajor challenges in the future include the development of strategies }}$ that will allow us to extrapolate from regional to global scales (for example, the validation of geophysical products and the reconciliation between scales of radar backscatter models and atmospheric general circulation models) and the development of new technology that will result in additional sensor capabilities (for example, 35- and $90-\mathrm{GHz}$ systems and lightweight electronics). Along with these advances will come many new applications of active microwave remote sensing (for example, precipitation mapping and subsurface mapping) that, in turn, will require new techniques for data processing and analysis.

In addition, several strategies are being pursued for the synthesis of other data sets and the geophysical information derived from SAR data. For example, multisensor classifications, which have included radar images as adjunct bandpasses to optical or infrared sensor systems (Blom and Daily, 1982; Rebillard and Evans, 1983; Evans, 1988), have reported improved classification accuracies over visible and infrared data alone. These studies, however, did not exploit the full diversity of the SAR sensors available at this time (for example, Evans and others, 1990). A different approach being investigated is to derive geophysical parameters from sensor systems independently and then do a combined interpretation on the derived geophysical products (Srinivasan and Richards, 1990; Evans, in press).

Finally, new data handling and analysis tools will be required in order to handle the enormous increase in SAR data that are expected over the next decade. The Magellan mission to Venus provided the first planetary-scale data base using SAR. Although complex in itself, future Earth-orbiting missions will acquire this same amount of data routinely so that changes can be monitored and possibly can be predicted.

\section{Acknowledgments}

This work was performed at the Jet Propulsion Laboratory, California Institute of Technology, and was sponsored by the National Aeronautics and Space Administration.

\section{References}

Arvidson, R.E., Evans, D.L., Farr, T.G., and others, in press, Characterization of lava flow degradation in the Pisgah and Cima volcanic fields, California, using remote sensing data: Geological Society of America Bulletin.

Blom, R.G., Crippen, R.J., and Elachi, Charles, 1984, Detection of subsurface features in Seasat radar images of Means Valley, Mojave Desert, California: Geology, v. 12 , no. 6, p. 346-349.

Blom, R.G., and Daily, Michael, 1982, Radar image processing for rock-type discrimination: IEEE [Institute of Electrical and Electronics Engineers] Transactions on Geoscience and Remote Sensing, v. GE-20, no. 3, p. 343-351.

Campbell, B.A., Zisk, S.H., and Mouginis-Mark, P.J., 1989, A quad-pol radar scattering model for use in remote sensing of lava flow morphology: Remote Sensing of Environment, v. 30, p. 227-237.
Cumming, Ian, Hawkins, David, and Gray, Laurence, 1990, All-weather mapping with interferometric radar: International Symposium on Remote Sensing of Environment, 23rd, Bangkok, 1990.

Dubois, P., Kustas, B., Sorooshian, S., Guerra, A., and van Zyl, J.J., 1991 , Monsoon '90 SAR results: JPL Airborne Geoscience Workshop, 2nd, Pasadena, California, USA, 1991.

Durden, S.L., van Zyl, J.J., and Zebker, H.A., 1989, Modelling and observation of the radar polarization signature of forested areas: IEEE Transactions on Geoscience and Remote Sensing, v. 27, no. 3, p. 290-301.

Engheta, N., and Elachi, C., 1982, Radar scattering from a diffuse vegetation layer over a smooth surface: IEEE Transactions on Geoscjence and Remote Sensing, v. GE-20, p. 212-216.

Engman, E., Saatchi, S., and van Zyl, J.J., 1991, MACHYDRO '90 results: JPL Airborne Geoscience Workshop, 2nd, Pasadena, California. USA, 1991.

Evans, D.L., 1988, Multisensor classification of sedimentary rocks: Remote Sensing of Environment, v. 25, no. 2, p. 129-144.

-_-in press, Current status and future developments in radar remote sensing: ISPRS [International Society for Photogrammetry and Remote Sensing] Journal of Photogrammetry and Remote Sensing,

Evans, D.L., Farr. T.G., Ford, J.P., Thompson, T.W., and Werner, C.L., 1986. Multipolarization radar images for geologic mapping and vegetation discrimination: IEEE Transactions on Geoscience and Remote Sensing. v. GE-24, no. 2. p. 246-257.

Evans. D.L., Farr, T.G., and van Zyl, J.J., in press, Estimates of surface roughness derived from Synthetic Aperture Radar data: IEEE Transactions on Geoscience and Remote Sensing.

Evans, D.L., Farr, T.G., van Zyl, J.J., and Zebker, H.A., 1988, Radar polarimetry: Analysis tools and applications: IEEE Transactions on Geoscience and Remote Sensing, v. 26, no. 6. p. 774-789.

Evans, D.L.. and Smith, M.O., 1991, Separation of vegetation and rock signatures in Thematic Mapper and polarimetric SAR images: Remote Sensing of Environment, v. 37, p. 63-75.

Evans, D.L., and van Zyl, J.J., 1990, Polarimetric imaging radar: Analysis tools and applications, in Kong, J.A., ed., Radar polarimetry, v. 3 of Progress in electromagnetic research: New York, Elsevier Science Publishers, p. 371-389.

Evans, D.L., van Zyl, J.J., and Burnette, C.F., 1990, Incorporation of polarimetric radar images into multisensor data sets: IEEE Transactions on Geoscience and Remote Sensing, v. 28, no. 5, p. 932-939.

Farr, T.G., in press, Microtopographic evolution of lava flows at Cima volcanic field, Mojave Desert, California: Journal of Geophysical Research.

Ford, J.P., and Casey, D.J., 1988, Shuttle radar mapping with diverse incidence angles in the rainforests of Borneo: International Journal of Remote Sensing, v. 9, p. 927-943.

Gabriel, A.K., Goldstein, R.M., and Zebker, H.A., 1989, Mapping small elevation changes over large areas: Differential radar interferometry: Journal of Geophysical Research, v. 94, no. B7, p. 9183-9191.

Gaddis, L., Mouginis-Mark, P.J., Singer, R.B., and Kaupp, V., 1989, Geologic analysis of Shuttle Imaging Radar (SIR-B) data of Kilauea Volcano, Hawaii: Geological Society of America Bulletin, v. 101, no. 3 , p. $317-332$.

Goldstein, R.M., Zebker, H.A., and Werner, C.L., 1988, Satellite radar interferometry: Two dimensional phase unwrapping: Radio Science, $v$. 23, no. 4, p. $713-720$

Greeley, R., and Martel, L., 1988, Radar observations of basaltic lava flows: International Journal of Remote Sensing, v, 9, no. 6, p. 1071-1085.

Imhoff, M., Story, M., Vermillion, C., Khan, F., and Polcyn, F., 1986, Forest canopy characterization and vegetation penetration assessment with spaceborne radar: IEEE Transactions on Geoscience and Remote Sensing, v. GE-24, p. 535-542

Imhoff, M.L., Vermillion, C., Story, M., Choudhury, A.M., Gafoor, A., and Polcyn, F., 1987, Monsoon flood boundary delineation and damage assessment with spaceborne radar: IEEE Transactions on Geoscience and Remote Sensing, v. GE-25, p. 405-413.

Jezek, K., Crawford, J.P., Bindschadler, R., Drinkwater, M.R., and Kwok, R.. 1991, Synthetic aperture radar observations of the Greenland ice sheets, in Airborne Synthetic Aperture Radar (AIRSAR) Workshop, 2nd, Pasadena, California, USA, Proceedings: JPL Publication 90-56, $57 \mathrm{p}$. 
Krohn, M.D., Milton, N.M., and Segal, D.B., 1983, SEASAT synthetic aperture radar (SAR) response to lowland vegetation types in eastern Maryland and Virginia: Journal of Geophysical Research, v, 88, no. C3, p. 1937-1952.

Lynne, G.J., and Taylor, G.R., 1986, Geological assessment of SIR-B imagery of the Amadeus Basin, N.T., Australia: IEEE Transactions on Geoscience and Remote Sensing, v. GE-24, no. 41, p. 575-581.

McCauley, J.F., Breed, C.S., Schaber, G.G., McHugh, W.P., Issawi, B., Haynes, C.V., Grolier, M.J., and El Kilani, A., 1986, Paleodrainages of the eastern Sahara-The radar rivers revisited (SIR-A/B implications for a mid-Tertiary trans-African drainage system): IEEE Transactions on Geoscience and Remote Sensing, v. GE-24, no. 4, p. 624-648.

McCauley, J.F., Schaber, G.G., Breed, C.S., Grolier, M.J., Haynes, C.V., Issawi, B., Elachi, C., and Blom. R., 1982, Subsurface valleys and geoarchaeology of the eastern Sahara revealed by Shuttle Radar: Science, v. 218 , no. 4576 , p. 1004-1020.

Mouginis-Mark, P.J., Rowland, S., Francis, P., and others, 1991, Analysis of active volcanoes from the Earth Observing System: Remote Sensing of Environment, v. 36, p. 1-12.

Ormsby, J.P., Blanchard, B.J., and Blanchard, A.J., 1985, Detection of lowland flooding using active microwave systems: Photogrammetric Engineering and Remote Sensing, v. 51, no. 3, p. 317-328.

Rebillard, P., and Evans, D.L., 1983, Analysis of coregistered Landsat, Seasat and SIR-A images of varied terrain types: Geophysical Research Letters, v. 10, no. 4, p. 277-280.

Richards, J.A., Sun, G., and Simonett, D., 1987, L-band radar backscatter modeling of forest stands: IEEE Transactions on Geoscience and Remote Sensing, v. GE-25, p. 487-498.

Rott, H., 1990, Snow and land ice in the climate system: Research problems and possibilities of remote sensing: Remote Sensing and the Earth's Environment, ESA [European Space Agency] SP-301, p. 61-75.

Sabins, F., 1983, Geologic interpretation of space shuttle radar images of Indonesia: American Association of Petroleum Geologists Bulletin, v. 67. p. 2076-2099.

Schaber, G.G., McCauley, J.F., Breed, C.S., and Olhoeft, R.R., 1986, Physical controls on signal penetration and subsurface scattering in the Eastern Sahara: IEEE Transactions on Geoscience and Remote Sensing, v. GE-24, no. 4, p. 603-623.

Srinivasan, A., and Richards, J.A., 1990, Knowledge-based techniques for multi-source classification: International Journal of Remote Sensing, v. 11 , no. 3 , p. $505-525$.

Stromberg, W.D., and Farr, T.G., 1986, A Fourier-based textural feature extraction procedure: IEEE Transactions on Geoscience and Remote Sensing, v. GE-24, no. 5 , p. $722-731$.

van Zyl, J.J., 1985, On the importance of polarization in radar scattering problems: Pasadena, California, USA, Ph.D. thesis, California Institute of Technology Antenna Lab Report no. 120, p. 32-33.

-1989 , Unsupervised classification of scattering behavior using radar polarimetry data: IEEE Transactions on Geoscience and Remote Sensing, v. 27 , no. 1 , p. $36-45$.
1990. Calibration of polarimetric radar images using only image parameters and trihedral corner reflector responses: IEEE Transactions on Geoscience and Remote Sensing, v. 28, no. 3, p. 337-348.

van Zyl, J.J., Burnette, C.F., and Farr, T.G., 1991, Inference of surface power spectra from inversion of multifrequency polarimetric radar data: Geophysical Research Letters, v. 18, no. 9, p. 1787-1790.

Wadge, G., and Dixon, T.H., 1984, A geological interpretation of Seasat SAR imagery of Jamaica: Journal of Geology, v. 92, p. 561-581.

Waite, W.P., MacDonald, H.C., Kaupp, V.H., and Demarke, J.S., 1981, Wetland mapping with imaging radar: IGARSS [International Geoscience and Remote Sensing Symposium] Digest 2, p. 794-799.

Wall, S.D., Farr, T.G., Muller, J.P., Lewis, P., and Leberl, F.W., 1991, Measurement of surface microtopography: Photogrammetric Engineering and Remote Sensing, v. 57, no. 8, p. 1075-1078.

Zebker, H.A., and Goldstein, R.M., 1986, Topographic mapping from interferometric synthetic aperture radar observations: Journal of Geophysical Research, v, 91, no. B5, p. 4993-4999.

Zebker, H.A., Madsen, S.N., Martin, J., Wheeler, K.B., Miller, T., Lou, Y., Alberti, G., Vetrella, S., and Cucci, A., in press, The TOPSAR interferometric radar topographic mapping instrument: IEEE Transactions on Geoscience and Remote Sensing. $\square$

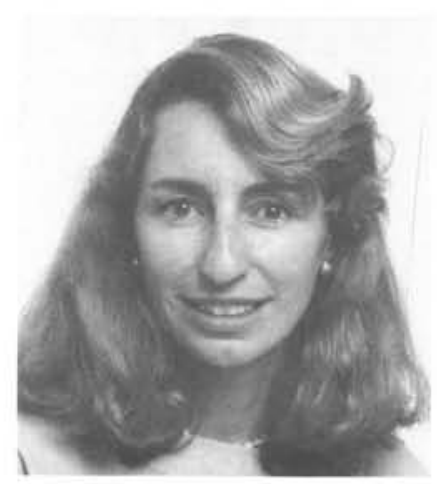

Diane L. Evans received her bachelor's degree in geology from Occidental College, Los Angeles, California, USA, in 1976 and her master's and doctoral degrees in 1978 and 1981 . respectively, in geological sciences from the University of Washington, Seattle, Washington, USA. She is Program Manager for the Earth Science Program and the Project Scientist for the Spaceborne Imaging Radar (SIR) projects at the Jet Propulsion Laboratory in Pasadena, California. She is also Principal Investigator for studies emphasizing the characterization of geologic surfaces by the use of multiparameter radar data and for the development of techniques for quantitative analysis of SAR images, as well as being a member of the ERS-1 and EOS SAR science team. 